\title{
Spatio-temporal assessment of ambient air quality, their health effects and improvement during COVID-19 lockdown in one of the most polluted cities of India
}

\author{
Markandeya $^{1}$ (D) Pradeep Kumar Verma ${ }^{2}$ - Vibhuti Mishra ${ }^{3}$ - Neeraj Kumar Singh ${ }^{4} \cdot$ Sheo Prasad Shukla $^{2,3}$. \\ Devendra Mohan ${ }^{5}$
}

Received: 10 June 2020 / Accepted: 13 October 2020 / Published online: 23 October 2020

(C) Springer-Verlag GmbH Germany, part of Springer Nature 2020

\begin{abstract}
The present work aims to investigate seasonal variations in air pollution levels in Lucknow and assess the ambient air quality of the city together with highlighting the health impacts of major pollutants like $\mathrm{PM}_{10}, \mathrm{PM}_{2.5}, \mathrm{SO}_{2}, \mathrm{NO}_{2}, \mathrm{~Pb}$, Ni and aerosols from 2010 to 2019. The maximum and minimum values of $\mathrm{PM}_{10}, \mathrm{PM}_{2.5}, \mathrm{SO}_{2}, \mathrm{NO}_{2}, \mathrm{~Pb}$ and Ni were found to be 270.75 and $122.45 \mu \mathrm{g} / \mathrm{m}^{3}$, 124.95 and $95.52 \mu \mathrm{g} / \mathrm{m}^{3}, 25.60$ and $8.05 \mu \mathrm{g} / \mathrm{m}^{3}, 75.65$ and $23.85 \mu \mathrm{g} / \mathrm{m}^{3}, 0.66$ and $0.03 \mu \mathrm{g} / \mathrm{m}^{3}$ and $0.07 \mathrm{and} 0.01 \mathrm{ng} / \mathrm{m}^{3}$, respectively. Health impact of particulate matter has also been assessed with AirQ+, and it was estimated that long-term exposure of $\mathrm{PM}_{10}$ was attributed to between 37 and $48 \%$ for post-neonatal (age 1-12 months) mortality rate due to all causes, whereas longterm attributable proportions in mortality due to exposure of $\mathrm{PM}_{2.5}$ were to about 19 to $28 \%$ from all causes. Further, an attempt has also been made to evaluate the impact of lockdown amid COVID-19 on the ambient air quality of Lucknow. During the lockdown, $\mathrm{PM}_{2.5}$ levels reduced by $65 \%$ (at Gomti Nagar), 23\% (at central school), 79\% (at Lalbagh) and 35\% (at Talkatora), due to which, air quality index of Gomti Nagar came down to 43, well below 50 which falls in the healthy range. $\mathrm{NO}_{2}$ levels also came down. However, levels of $\mathrm{SO}_{2}$ did not show significant reduction. Correlating the data between aerosol optical depth and Angstrom exponent by Pearson correlation analysis revealed a significant positive correlation $(r=0.65, P<0.001)$.
\end{abstract}

Keywords Air pollution $\cdot$ Aerosol $\cdot$ AirQ+ $\cdot$ Lockdown $\cdot$ AQI $\cdot$ Health effect

\section{Highlights}

- Spatio-temporal assessment of various pollutants like $\mathrm{PM}_{10}, \mathrm{PM}_{2.5}$, $\mathrm{SO}_{2}, \mathrm{NO}_{2}, \mathrm{~Pb}, \mathrm{Ni}$ and atmospheric aerosols from 2010 to 2019 was performed.

- AQI score for most of the studied locations was found in the poor category.

- During the lockdown, AQI scores decreased to well below 50, in the healthy range.

- High AE value was observed in October to November because of stubble burning during the harvest season in Northern India.

- The health impact of air pollutants was estimated using AirQ+ software.

- Long-term exposure to $\mathrm{PM}_{2.5}$ to ambient air increased the risk of stroke by $20 \%$.

Responsible Editor: Gerhard Lammel

\footnotetext{
Markandeya

mktiwariiet@gmail.com

$\triangle$ Devendra Mohan devmohan9@gmail.com

1 Ex-Department of Civil Engineering, Indian Institute of Technology (BHU), Varanasi 221005, India

2 Rajkiya Engineering College, Banda 210201, India
}

3 Department of Civil Engineering, Institute of Engineering and Technology, Lucknow 226021, India

4 Central Mine Planning and Design Institute Limited (CMPDIL), Regional Institute-7, Bhubaneswar 751001, India

5 Department of Civil Engineering, Indian Institute of Technology (BHU), 751001 Varanasi, India 


\section{Introduction}

Infamous for being one of the most polluted cities in the world, Lucknow, the capital city of Uttar Pradesh, has witnessed unprecedentedly high levels of air pollution over the past few years. Clean air should be an unlimited free natural resource and the basic need of all living beings. Against a daily requirement of $2 \mathrm{~kg}$ of food and $3 \mathrm{~L}$ of water, an adult inhales and exhales about $8 \mathrm{~L}$ of air every single minute. But when this life-sustaining air gets polluted, it can have dire effects not only on humans but also on plants, animals and all living organisms (Ghorani-Azam et al. 2016). Today, the air we breathe is being polluted by various natural and anthropogenic sources like accelerated industrialization, haphazard urbanization, rapid increase in human population and everburgeoning number of automobiles on the roads (Satterthwaite et al. 2010). Natural processes absorb these pollutants to a certain extent and air quality is restored, but when the limits are exceeded, pollutants accumulate in the environment and air quality deteriorates. As per WHO data of 2006 , more than $80 \%$ of urban dwellers are exposed to air quality levels that exceed WHO guideline limits (WHO 2006). However, as per recent 2016 data of WHO, it has now been observed in $90 \%$ of total world population (WHO 2016). Over the past few decades, human involvement has drastically modified Earth's chemistry and climate. The emissions from automobiles, prolific burning of fossil fuels, industrial activities and intensification of agricultural practices have escalated the ambient concentration levels of harmful gases like $\mathrm{SO}_{2}, \mathrm{NO}_{2}$ and $\mathrm{CO}$ and of $\mathrm{O}_{3}$ and particulate matter (PM) to worrying levels (Gurjar et al. 2016; Wu et al. 2020). Effect of $\mathrm{SO}_{2}$ on ecosystem and human health is well known. Shortterm exposure harms the respiratory system, particularly in children and elderly people (Pandey et al. 2011, 2013). It reacts with other gaseous particles in the air to form haze and thereby reduces visibility. Longer exposures to elevated concentrations of $\mathrm{SO}_{2}$ can aggravate existing heart and lung diseases. Epidemiological studies associate $\mathrm{NO}_{2}$ and $\mathrm{CO}$ with increased cardiovascular mortality, cerebrovascular diseases and ischaemic heart diseases (Atkinson et al. 2018). High concentration of $\mathrm{CO}$ in air reduces oxygen supply to critical organs like heart and brain, causing dizziness, unconsciousness and even death. As per the Indian Nitrogen Assessment report 2018, between 1991 and 2001, $\mathrm{NO}_{x}$ emissions grew at $52 \%$ and at 69\% from 2001 to 2011 (Pathak and Bhatia 2018). The sources of heavy metals in urban air include vehicular exhaust, untreated industrial effluents, street dust and other anthropogenic activities. Elevated concentrations of all the metals are harmful to living organisms. Though there are various routes by which these metals can enter inside the body, inhalation of particles $(\leq 10 \mu \mathrm{m})$ is the commonest (Winkler et al. 2018; Zhang and Batterman 2013). The inorganic components constitute only a small portion by mass of the particulates; however, they contain some toxic elements which are potential carcinogens even in trace amounts (Shukla et al. 2008).

There is not an iota of doubt in the fact that deteriorating environment with worsening air quality, damaged landscapes and degraded towns would cost us dearly not only in economic terms but also in terms of our physical health and quality of life (Seinfeld and Pandis 1998). Lucknow, the state capital of Uttar Pradesh, was ranked as the ninth most polluted city in the world, as per the report published in March 2019. Within a very short period of time, the city could face serious problems if sincere efforts are not made to regulate and control pollution. There is, therefore, an urgent need to undertake proper carrying capacity studies and planned development of the city.

The use of clean fuel with low sulphur content is considered an effective measure to arrest the rising level of pollution in urban areas (Markandeya et al. 2016a, b). Prompted by the deteriorating air quality in Indian cities like Lucknow, the government has launched several flagship initiatives including implementation of stringent emission norms, strict pollution control measures, improved technology for combustion engines and phasing out of polluting 2 -stroke engines. The government has also introduced compressed natural gas $(\mathrm{CNG})$ in public transport system, which is $50 \%$ cleaner than coal on carbon emissions and significantly cleaner on $\mathrm{SO}_{x}$ and $\mathrm{NO}_{x}$ and has virtually non-existent $\mathrm{PM}_{2.5}$. Despite these efforts, vehicular pollution continues to remain the primary source of increasing air pollution in Lucknow City (Barman et al. 2008; assessment report CSIR-IITR 2010-2019), leading to generation of a vast amount of PM, noxious gases and heavy metals that push the pollution in the city to unbearable levels.

Atmospheric aerosols consist of solid or liquid particles suspended in the atmosphere and include a wide range of phenomena such as dust, smoke, haze, fume, smog, fog and mist (Seinfeld and Pandis 1998; Markandeya et al. 2017). PM refers just to the suspended solid or liquid matter, whereas an aerosol is a collection of suspended particles and the surrounding gases. Aerosols are produced from a variety of anthropogenic and natural sources with a typical size ranging from 0.001 to $10 \mu \mathrm{m}$. Natural aerosol particle includes sulphate aerosols from volcanic eruption, sea salt particle from ocean surface, mineral dust aerosols and wind borne dust (Shen et al. 2019; You et al. 2020). Aerosol loading or the amount of aerosols in the atmosphere is usually quantified by mass concentration or by an optical measure, i.e. aerosol optical depth (AOD). Thus, AOD is the qualitative measure of extinction of solar radiation by aerosol scattering and absorption between the points of observation and top of the atmosphere (Kumar et al. 2019; Tiwari et al. 2014, 2015). Angstrom exponent $(\mathrm{AE})$ is a qualitative indicator of aerosol particle size. Higher $\mathrm{AE}$ values are a reflection of the fact that fine-mode aerosols are dominating, while lower $\mathrm{AE}$ values indicate dominance of coarse-mode aerosols (Das and Jayaraman 2011). Due to 
coagulation, the size of fine-mode particles is altered, resulting in increasing aerosol loading under suitable atmospheric condition, thereby leading to an increase of the concentration of coarse-mode particles (Das et al. 2015). The Moderate Resolution Imaging Spectroradiometer onboard two Earth Observing System (EOS) Terra and Aqua satellites at an altitude of $705 \mathrm{~km}$ measures reflected solar radiance and terrestrial emission in 36 bands ranging from 0.4 to $14.4 \mu \mathrm{m}$ wavelength with the different spatial resolutions of 0.25 and $1 \mathrm{~km}$ (Gupta et al. 2013). All the above-mentioned facts necessitate the assessment of ambient air quality with respect to respirable suspended particulate matter $\left(\mathrm{PM}_{10}\right.$ and $\left.\mathrm{PM}_{2.5}\right), \mathrm{SO}_{2}, \mathrm{NO}_{2}$, metals (lead $(\mathrm{Pb})$ and $\mathrm{Ni}$ ) and aerosols in Lucknow City area. In this study, we observed long-term temporal and spatial variations of different ambient air pollutants and health impacts of particulate matters by using AirQ+ software. The study also investigates the impact of lockdown on the air quality of Lucknow City.

\section{Materials and methods}

\section{Monitoring location}

A total of nine air quality monitoring locations in different areas, i.e. four in residential (Aliganj, Indira Nagar, Vikas Nagar, Gomti Nagar), four in commercial cum traffic (Charbagh, Aminabad, Alambagh, Chowk) and one industrial area (Amausi) were selected for this study (Fig. 1).

\section{Data collection}

\section{Air quality data}

Particulate matters $\left(\mathrm{PM}_{10}\right.$ and $\left.\mathrm{PM}_{2.5}\right)$ were measured using a gravimetric method, sulphur dioxide $\left(\mathrm{SO}_{2}\right)$ was measured using the improved West-Gaeke method, nitrogen dioxide $\left(\mathrm{NO}_{2}\right)$ was measured using the modified Jacobs-Hochheiser (Na-arsenite) method and trace metals ( $\mathrm{Pb}$ and $\mathrm{Ni}$ ) were measured using an AAS method after sampling on EPM 2000. Air quality data was obtained from our past Institute CSIR-IITR, Lucknow, which has the responsibility to assess the ambient air quality of Lucknow City in two phases: pre-monsoon (November to May, report released on June 5) and postmonsoon (June to October, report released on November 5). The sampling frequency was 24 hourly, twice in a month. Ten-year data from 2010 to 2019 was used in this study.

\section{Data during lockdown}

For assessment of day-to-day real-time air quality, a total number of four Continuous Ambient Air Quality Monitoring Stations (CAAQMS) have been installed in Lucknow. Out of these four stations, two CAAQMS are installed in residential areas, i.e. Gomti Nagar and Aliganj (central school). The remaining two have been installed in commercial and industrial areas, i.e. Lalbagh and Talkatora. To assess the impact of lockdown on the air quality, fortnight data before lockdown (February 21, 2020, to March 21, 2020) and during lockdown (March 22, 2020, to April 20,2020) have been taken into consideration.

\section{$A O D$ and $A E$ data}

The remote sensing instrument called Moderate Resolution Imaging Spectroradiometer (MODIS) permits the scientist to monitor various characteristics of the Earth's terrestrial and oceanic surfaces with a single instrument, also facilitating the analysis of aerosols from the space with maximum accuracy. $\mathrm{AE}$ and $\mathrm{AOD}$ datasets used in this study were retrieved from both MODIS Terra and Aqua satellites and downloaded from NASA Giovanni website (https://giovanni.gsfc.nasa. gov/giovanni/) of level 3 Collection 6.1, which is globally available with $1^{\circ} \times 1^{\circ}$ resolution, and averaged values of the daily mean of area were employed in the range of latitude from 26.35 to $27.35^{\circ} \mathrm{N}$ and longitude of $80.45-81.45^{\circ} \mathrm{E}$, centralized at Lucknow $\left(26.85^{\circ} \mathrm{N}, 80.95^{\circ} \mathrm{E}\right)$ for the period January 2010 to March 2020. In the present study, AOD data at a wavelength of $550 \mathrm{~nm}$ and $\mathrm{AE}$ at $412 \mathrm{~nm} / 470 \mathrm{~nm}$ over land are used as they are associated with major radiative effects and are close to the peak of solar spectrum.

\section{Data analyses}

\section{Air quality data}

Data was divided into three segments: first was residential area (Aliganj, Indira Nagar, Vikas Nagar and Gomti Nagar), second was commercial area (Charbagh, Aminabad, Alambagh and Chowk) and third was industrial area (Amausi). The data is collected from CSIR-Indian Institute of Toxicology Research as our Institute covers whole-year data, and published in the form of report as pre-monsoon (November to May) and post-monsoon (June to October). It is the whole-year data. The sampling frequency was twice in a month for 24 hourly. Data was summarized as average, minimum and maximum of the pre-monsoon and post-monsoon average data.

\section{Lockdown data}

A map of Lucknow has been digitized, and different layers, i.e. continuous air monitoring stations, major roads and railway lines, have been generated. Three criteria of pollutants $\left(\mathrm{PM}_{2.5}, \mathrm{SO}_{2}\right.$ and $\left.\mathrm{NO}_{2}\right)$ have been selected, and their fortnight data before and during lockdown has been collected from the CAAQMS real-time data bank of Central Pollution Control 
Fig. 1 Monitoring location of the study area in Lucknow City

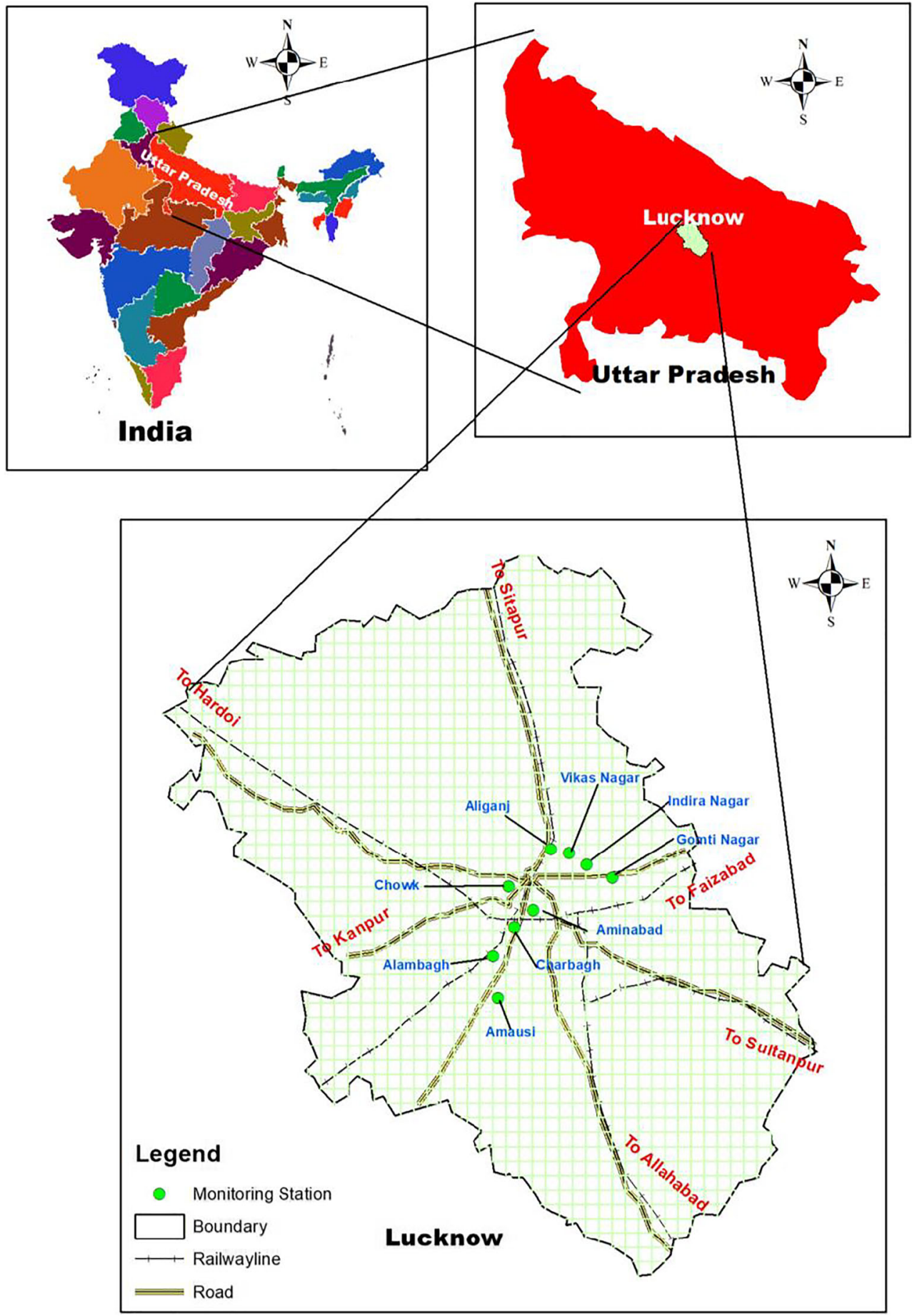

Board (CPCB). Average values of all three pollutants have been calculated for before and during lockdown period. For air quality index (AQI), the methodology adopted by $\mathrm{CPCB}$, the sub-index against each pollutant and the resultant AQI will be the maximum of these sub-indexes (AQI-CPCB 2020). The sub-index $\left(I_{p}\right)$ is calculated for individual pollutants $\left(C_{\mathrm{p}}\right)$ based on 'linear segment principle' by using the following equation (Eq. (1)):
$I_{p}=\left[\frac{I_{\mathrm{HI}}-I_{\mathrm{LO}}}{B_{\mathrm{HI}}-B_{\mathrm{LO}}} \times C_{\mathrm{p}}-B_{\mathrm{LO}}\right]+I_{\mathrm{LO}}$

where $B_{\mathrm{HI}}$ is the breakpoint concentration greater or equal to the given concentration, $B_{\mathrm{LO}}$ is the breakpoint concentration smaller or equal to the given concentration, $I_{\mathrm{HI}}$ is the AQI value corresponding to $B_{\mathrm{HI}}$ and $I_{\mathrm{LO}}$ is the AQI value corresponding to $B_{\mathrm{LO}}$; subtract one 
from $I_{\mathrm{LO}}$, if $I_{\mathrm{LO}}$ is greater than 50 , and finally, AQI is the $\max \left(I_{p}\right)$ (where $p$ is $1,2, \ldots, n ; n$ denotes pollutants).

In the present study, during AQI calculation at all 4 locations, it has been observed that every time the sub-index of $\mathrm{PM}_{2.5}$ was maximum compared to $\mathrm{SO}_{2}$ and $\mathrm{NO}_{2}$. Average pollutant data along with AQI values before and during lockdown were mapped to monitoring stations' database, and spatial maps were generated in ArcGIS, version 10.7.1.

\section{Data analysis between AOD and AE}

Aerosol data was summarized as mean $\pm \mathrm{SD}$. AOD and $\mathrm{AE}$ groups were compared by one-way analysis of variance (ANOVA). Pearson correlation analysis was done to assess the association between AOD and AE datasets. The statistical software Origin (version 9.1) was used for the analysis of data (Markandeya et al. 2015).

\section{Health effects}

The AIRQ+ software developed by WHO, updated in 2018, was used for the estimation of health impact assessment of $\mathrm{PM}_{10}$ and $\mathrm{PM}_{2.5}$ in this study. Relative rise (RR) is the estimation of the magnitude of an association between exposure and disease. It indicates the probability of developing the disease in the exposed group relative to those who are not exposed. Probability is the ratio of developing the disease in the exposed group to that in the non-exposed group. It also indicates the probability of developing the disease in the exposed area at the given time period. Here, we assumed RR to be equal to $1.04(95 \% \mathrm{CI}=1.02$ to 1.07$)$ for the neonatal age group at baseline $\mathrm{PM}_{10}\left(50 \mu \mathrm{g} / \mathrm{m}^{3}\right)$. On the other hand, the RR taken for $\mathrm{PM}_{2.5}$ was $1.07(95 \% \mathrm{CI}=1.05$ to 1.09$)$ for all causes of mortality at baseline $\mathrm{PM}_{2.5}\left(40 \mu \mathrm{g} / \mathrm{m}^{3}\right)$.

$\mathrm{RR}$ is usually modelled with a log-linear function as given in Eq. (2)

$\mathrm{RR}=\frac{\exp \left(\alpha+\beta X_{i}\right)}{\exp \left(\alpha+\beta X_{0}\right)}=\exp \left[\beta\left(X-X_{0}\right)\right]$

where $X_{i}$ is the pollutant concentration $\left(\mu \mathrm{g} / \mathrm{m}^{3}\right)$ and $X_{0}$ is the cut-off or counterfactual $\left(\mu \mathrm{g} / \mathrm{m}^{3}\right)$. In the log-linear model, $\beta$ is the change in the RR for a 1-unit change in the concentration $X_{i}$.

\section{Results and discussion}

\section{Analysis of air quality data}

The maximum average values for $\mathrm{PM}_{10}$ and $\mathrm{PM}_{2.5}$ were 271 and $125 \mu \mathrm{g} / \mathrm{m}^{3}$, respectively, and the yearly average values of both these pollutants for the stated period (2010 to 2019) were 199 and $96 \mu \mathrm{g} / \mathrm{m}^{3}$, respectively (Fig. 2a, b). These are much higher than those prescribed by the National Ambient Air Quality Standards (NAAQS) $\left(60 \mu \mathrm{g} / \mathrm{m}^{3}\right.$ for $\mathrm{PM}_{10}$ and $40 \mu \mathrm{g} / \mathrm{m}^{3}$ for $\mathrm{PM}_{2.5}$ ). Area-wise, almost all the considered areas reported high particulate pollution, but two commercially important areas, namely Charbagh and Chowk, were worst affected. Charbagh had the highest values for both $\mathrm{PM}_{10}$ and $\mathrm{PM}_{2.5}$, where the average level was always higher than $199.33 \mu \mathrm{g} / \mathrm{m}^{3}$ for $\mathrm{PM}_{10}$ and $95.52 \mu \mathrm{g} / \mathrm{m}^{3}$ for $\mathrm{PM}_{2.5}$, much above the permissible limits.

Since particulate matter is the dominant pollutant in most areas of the city, AQI values are directly linked to the level of particulate matter in the air. AQI values from 150 to 200 fall in the unhealthy category (CPCB 2006-2007). At such level of pollution, everyone may begin to experience health effects; especially, members of sensitive groups may experience more serious health problems, and active children and adults and people with a respiratory disease, such as asthma, should avoid prolonged outdoor exertion. Such high particulate pollution in Lucknow is in line with the findings of the IQ Air report (2019) which highlights that, on average, most Indian cities exceed the WHO guidelines for the amount of $\mathrm{PM}_{2.5}$ in the atmosphere by nearly 500\% (IQAir report 2019).

Pollutants settle down on the ground with the raindrops. As a result, their level in the air decreases drastically during the monsoon season. From Table 1, it can be observed that postmonsoon $\mathrm{PM}_{10}$ levels were less than pre-monsoon levels for all the years from 2010 to 2019, with 2015 being the only exception. This may be due to the reason that 2015 was a strong El Nino year due to which there was much less rainfall during the south-west monsoon season. Less rain results in less scavenging of the pollutants from the atmosphere (Shukla et al. 2008).

In contrast to all other considered pollutants, the levels of $\mathrm{SO}_{2}$ in commercial areas were not much different from those observed in residential and industrial areas. The commercial area of Alambagh reported higher average $\mathrm{SO}_{2}$ levels than Charbagh, Chowk and Amausi (Fig. 2c). Though the concentrations of $\mathrm{SO}_{2}$ reported from all the sampling stations are well below the prescribed NAAQS level $\left(80 \mu \mathrm{g} / \mathrm{m}^{3}\right)$, consistently high levels in the early post monsoon could be attributed to the stable meteorological conditions. Ghosh et al. (2018) also found that the concentration of $\mathrm{SO}_{2}$ was higher in post monsoon, which is similar to the present study.

Just like $\mathrm{SO}_{2}, \mathrm{NO}_{2}$ concentrations peaked during November to January and were minimum during July to August (Fig. 2c, d), possibly due to a large number of factors like low solar intensity resulting in decreased photochemical loss, anthropogenic emissions, boundary layer processes and local surface wind pattern. Similar observations have been reported from other urban locations like Ahmedabad and Pune, in India (Beig et al. 2013). For almost all the considered 

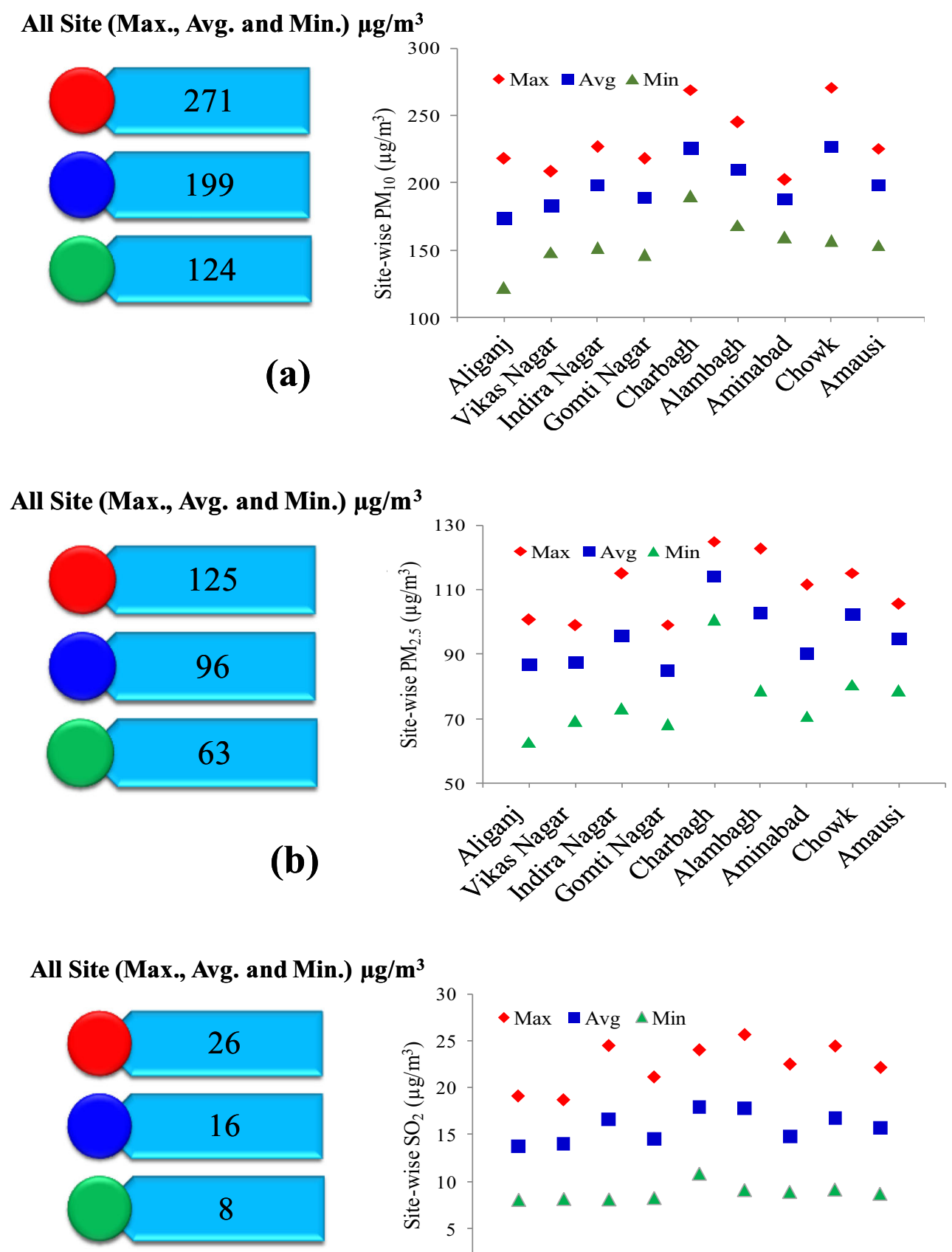

(c)

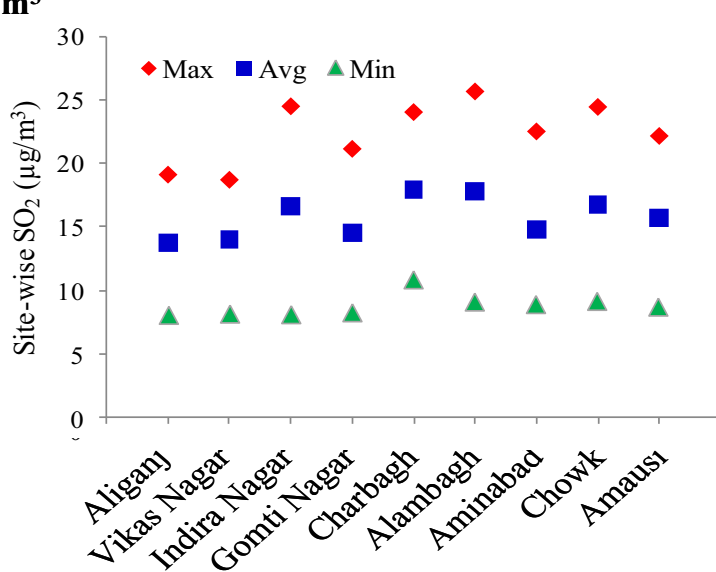

Fig. 2 Variations of the concentration of pollutants $\left(\mathbf{a} \mathrm{PM}_{10}, \mathbf{b} \mathrm{PM}_{2.5}, \mathbf{c ~ S O} 2, \mathbf{d ~ N O} \mathrm{SO}_{2}, \mathbf{e ~} \mathrm{Pb}\right.$ and $\left.\mathbf{f} \mathrm{Ni}\right)$ in air quality at different areas of Lucknow City

areas, the levels of $\mathrm{NO}_{2}$ were higher than $40 \mu \mathrm{g} / \mathrm{m}^{3}$ (NAAQS 2009). The silver lining is that the $\mathrm{NO}_{2}$ concentrations at Lucknow were still comparatively lower than those observed at other urban regions of the country.

Pollution levels in most regions of North India during the onset of winters reach unbearable levels, engulfing huge areas in thick smog, Lucknow being no exception. This is due to a combination of factors like increased biomass burning, festive season that culminates with the bursting of firecrackers on the night of Deepawali and a weather pattern which according to experts brings dust-bearing winds from West Asian countries like Iraq, Saudi Arabia and Kuwait. These winds collide with the moisture-bearing wind system coming from the east. Moisture locks in the dust and becomes a cloud. At the same 


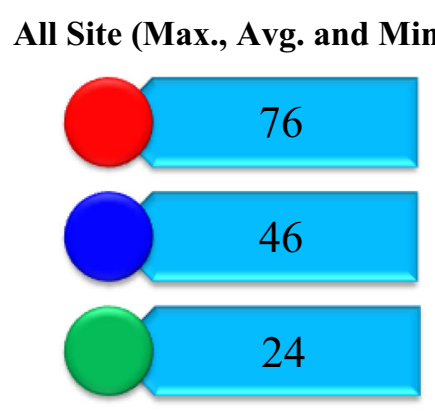

(d)
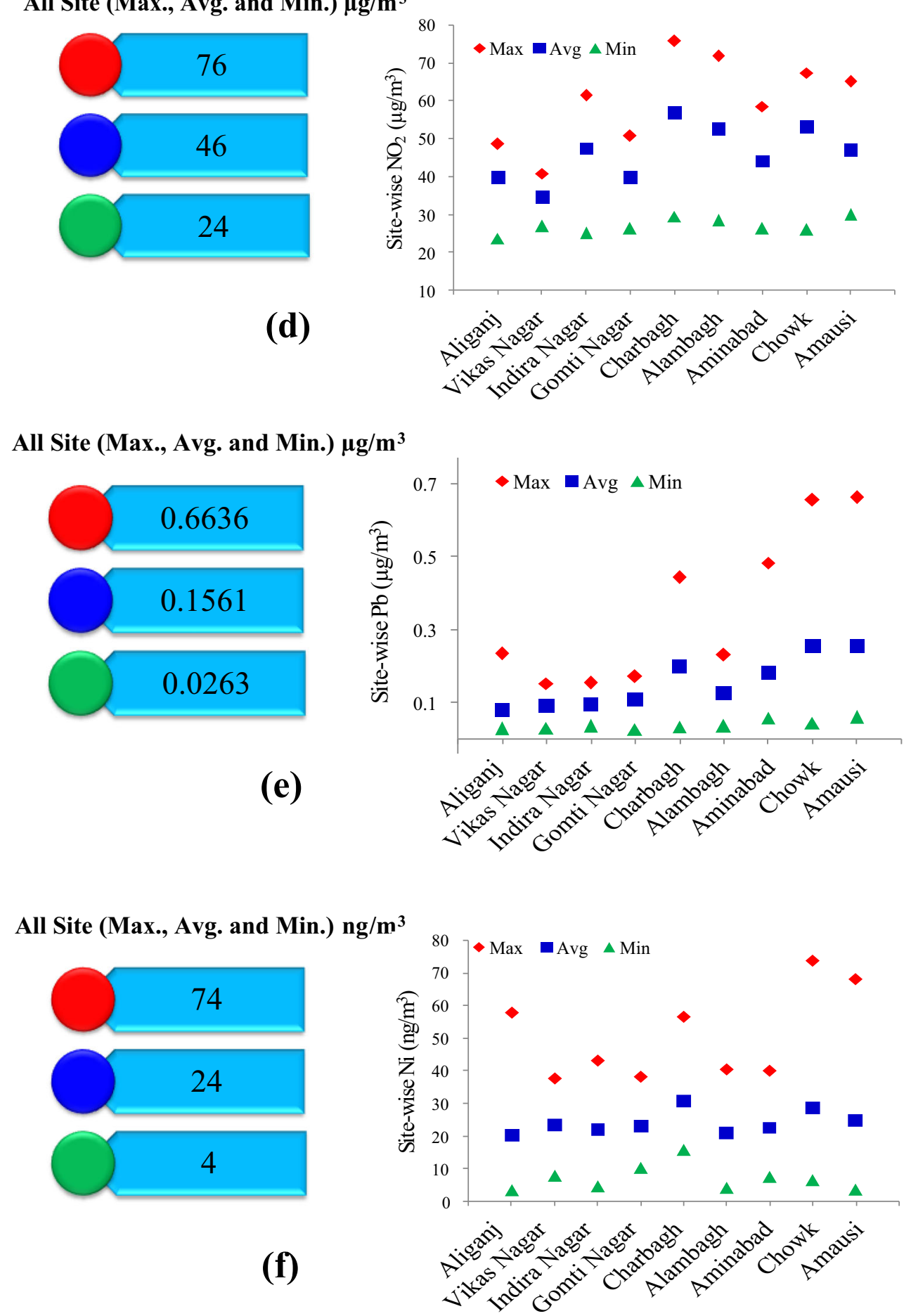

Fig. 2 (continued)

time, there is no wind at the ground level. This creates suffocating conditions (Havens et al. 2018).

As a result of EPA's regulatory efforts including the removal of $\mathrm{Pb}$ from motor vehicle gasoline, levels of $\mathrm{Pb}$ in the air decreased by $98 \%$ between 1980 and 2014 (Hai et al. 2018). Still high level of $\mathrm{Pb}$ pollution is an important issue in Lucknow. From Fig. 2e, it can be observed that the level of aerial $\mathrm{Pb}$ in commercial and industrial areas is almost double that of residential areas. Chowk and Amausi are the two main areas grappling with $\mathrm{Pb}$ pollution, where the recorded levels were as high as $0.664 \mu \mathrm{g} / \mathrm{m}^{3}$. These are higher than the NAAQS-prescribed limit of $0.5 \mu \mathrm{g} / \mathrm{m}^{3}$. The average value is 


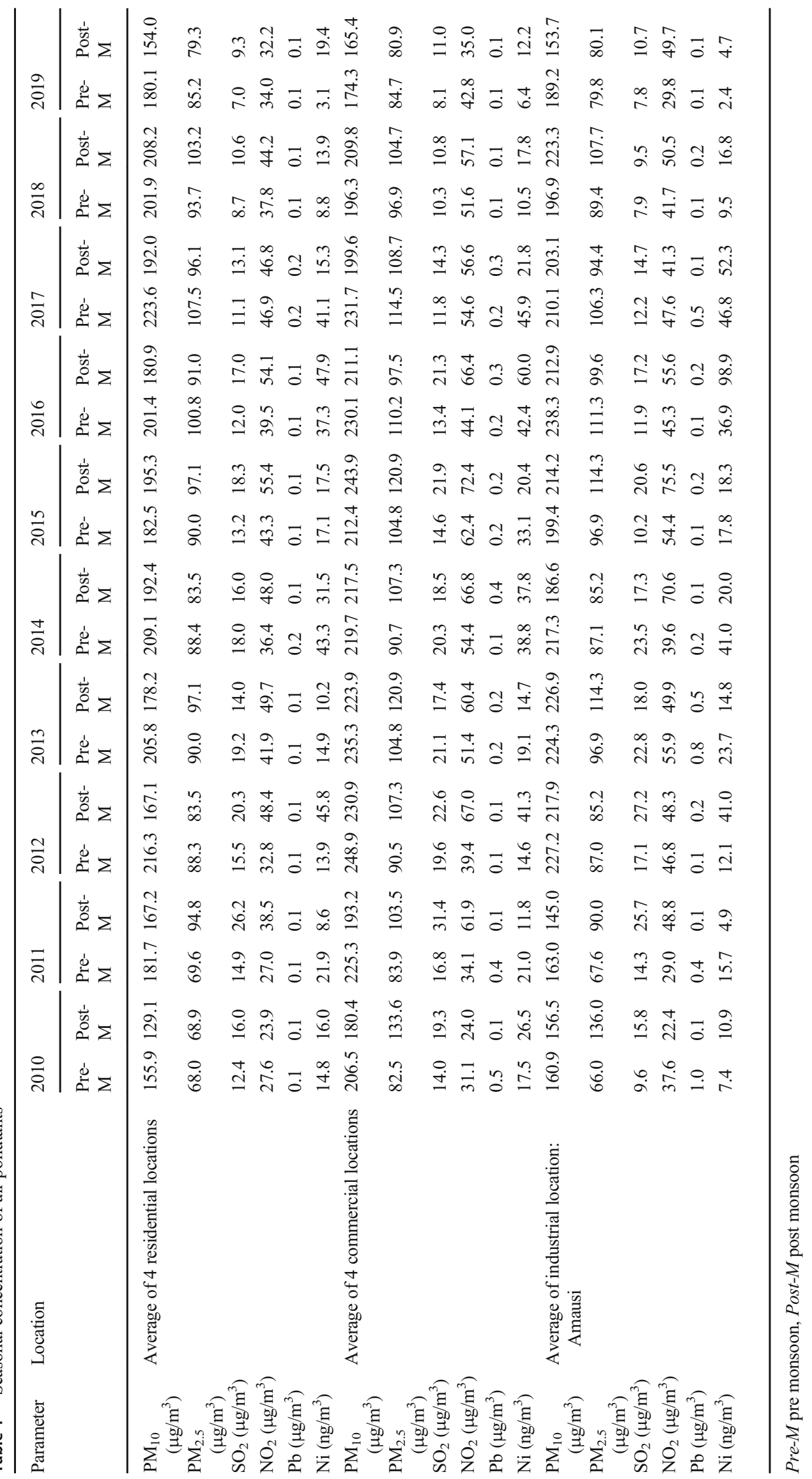


$0.16 \mu \mathrm{g} / \mathrm{m}^{3}$, but since $\mathrm{Pb}$ as a pollutant has no known safe threshold (there is no known sufficiently small amount of $\mathrm{Pb}$ that does not cause harm).

Environmental Ni levels depend particularly on natural sources, pollution from nickel-manufacturing industries and airborne particles from combustion of fossil fuels (US EPA 1999). There was a huge variation observed between the highest and lowest average values of $\mathrm{Ni}$, the former being as high as $74 \mathrm{ng} / \mathrm{m}^{3}$ and the latter $4 \mathrm{ng} / \mathrm{m}^{3}$ (Fig. 2f). The average value of $24 \mathrm{ng} / \mathrm{m}^{3}$ for the stated period of the study was higher than the permissible limit of $20 \mathrm{ng} / \mathrm{m}^{3}$ (NAAQS). Chowk and Amausi were the worst affected areas.

\section{Data analysis before and during lockdown}

Lockdown brought everything to a grinding halt, advocating blanket ban on all types of construction activities and restricting non-essential travels. As a result, vehicle density on the roads reduced drastically, ensuring a substantial drop in air pollution levels. Table 2 shows the comparison of the ambient air quality of Lucknow City before and after lockdown.

Based on Eq. (1), AQI has been calculated for all the four locations before and during lockdown. The details of AQI values are given in Table 2.

In the present study during AQI calculation at all 4 locations, it has been observed that every time the sub-index of $\mathrm{PM}_{2.5}$ was maximum compared to $\mathrm{SO}_{2}$ and $\mathrm{NO}_{2}$. Average pollutant data along with AQI values before and during lockdown were mapped to monitoring stations' database, and spatial maps were generated.

Figure 3 a shows that, during lockdown, a gradual uniform reduction of $\mathrm{PM}_{2.5}$ has been observed at all locations, whereas from Fig. 3b, it can be observed that no such significant variation has been observed in values of $\mathrm{SO}_{2}$ before and during lockdown. Before lockdown, the values of $\mathrm{NO}_{2}$ were higher in residential areas compared to industrial areas (Fig. 3c). But during lockdown, $\mathrm{NO}_{2}$ values in residential areas were less than those in industrial areas. It may be due to the fact that, in residential areas, the major and prime source of $\mathrm{NO}_{2}$ is

Table 2 AQI before and during lockdown

\begin{tabular}{|c|c|c|c|c|c|c|c|c|}
\hline \multirow[t]{3}{*}{ Locations } & \multicolumn{4}{|c|}{ Before lockdown } & \multicolumn{4}{|c|}{ During lockdown } \\
\hline & \multicolumn{3}{|c|}{ Sub-index } & \multirow[t]{2}{*}{ AQI } & \multicolumn{3}{|c|}{ Sub-index } & \multirow[t]{2}{*}{ AQI } \\
\hline & $\mathrm{PM}_{2.5}$ & $\mathrm{SO}_{2}$ & $\mathrm{NO}_{2}$ & & $\mathrm{PM}_{2.5}$ & $\mathrm{SO}_{2}$ & $\mathrm{NO}_{2}$ & \\
\hline Gomti Nagar & 71 & 18 & 35 & 71 & 43 & 14 & 11 & 43 \\
\hline Central School & 79 & 10 & 35 & 79 & 64 & 9 & 8 & 64 \\
\hline Lalbagh & 213 & 5 & 30 & 213 & 119 & 5 & 20 & 119 \\
\hline Talkatora & 174 & 4 & 35 & 174 & 129 & 4 & 15 & 129 \\
\hline
\end{tabular}

vehicular pollution. In high-traffic density areas, $\mathrm{NO}_{2}$ concentration was higher at all residential locations before lockdown, but during lockdown, all vehicular movements got suspended due to which a sharp decline was observed in the values of $\mathrm{NO}_{2}$. But in industrial area, the activity continued with little reduction of the man power. From Fig. 3d, it can be observed that, before lockdown, the major areas of Lucknow were severely and moderately polluted, whereas during lockdown, major areas of Lucknow had satisfactory air quality index.

\section{Relationship between AOD and AE values}

The spectral characteristics of AOD suggest about potential aerosol particles (course and fine) and their size distribution. The annual mean distribution of AOD and AE for the period of 2010 to 2019 over Lucknow City is presented in Fig. 4. The highest value of AOD was observed in 2016 while lowest was observed in 2010 with a range of $0.76 \pm 0.34$ to $0.56 \pm 0.25$. Tiwari et al. (2018) also reported nearly similar AOD value (0.64) over Kanpur City.

Srivastava et al. (2012) value was $0.63 \pm 0.21$, and the current study (with a value of 0.64 ) presented nearly similar results for annual average. Larger value of AOD in November, December and January may be due to high burning of biomass/agriculture residue and atmospheric condition, while in June and July, it may be due to less data availability of AOD due to cloud interference and water-absorbing type of aerosols. Analysis showed that the highest monthly mean value of AOD was found in the month of November $(0.95 \pm 0.11)$ and December $(0.95 \pm 0.23)$ followed by January $(0.95 \pm 0.19)$, while the lowest monthly mean value of AOD was observed in March $(0.39 \pm 0.05)$. Observation further showed that the decadal mean of AOD value during the study period is $0.65 \pm$ 0.27 , which is nearly similar to the decadal AOD value of Varanasi $(0.67 \pm 0.28)$, Patna $(0.65 \pm 0.30)$ and Kolkata $(0.5$ \pm 0.21 ) (Kumar et al. 2018). AOD during monsoon season $(0.80 \pm 0.18)$ is high as compared to that during summer season $(0.54 \pm 0.19)$, possibly due to the hygroscopic growth of water-soluble aerosols.

The annual mean value of $\mathrm{AE}$ ranging from $1.47 \pm 0.32$ to $1.06 \pm 0.53$ was observed over Lucknow during 2010 to 2019 , suggesting the presence of mostly fine-mode particles (emitted from anthropogenic sources, e.g. vehicular, industrial and biomass burning). Further, analysis showed the highest value of monthly mean AE in January (1.66 \pm 0.09$)$, but the lowest value in May $(0.60 \pm 0.11)$, with a wide range due to daily variations in weather condition and diverse emission sources. Figure 5 shows the monthly mean relation between AOD and AE during 2010 to 2019. Analysis showed that AOD and AE followed the same trend, except August, September and October that are opposite. Tiwari et al. (2018) observed that $\mathrm{AE}$ values $1.16 \pm 0.11$ and $1.2 \pm 0.09$ 

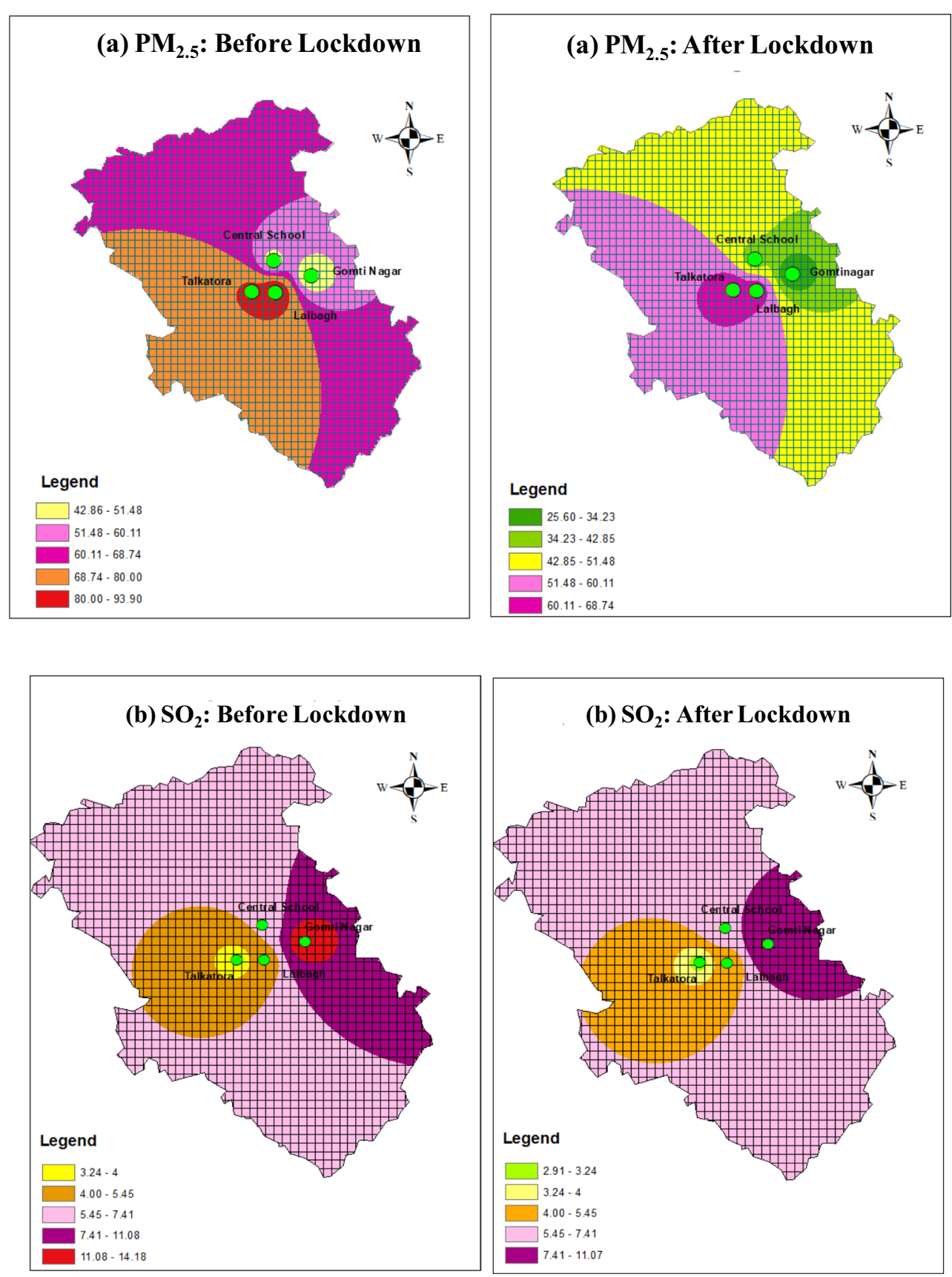

Fig. 3 Variations in $\mathrm{PM}_{2.5}$ (a), $\mathrm{SO}_{2}(\mathbf{b}), \mathrm{NO}_{2}$ (c) and $\mathrm{AQI}(\mathbf{d})$ in air quality before and during lockdown at different areas of Lucknow City

for type I and type II, respectively, indicates the dominance of fine-mode aerosol due to anthropogenic activity.

Figure 6 represents the seasonal annual correlation between AOD and AE, pre monsoon (Fig. 6a) and post monsoon (Fig. 6b). AE is the size indicator: small for coarse-mode aerosol particles and large for fine-mode aerosol particles. From Fig. 6, it is clear that AOD correlated with AE in both seasons and in summer due to high dust loading, in which AOD increases but $\mathrm{AE}$ decreases because of the larger size of dust particles (course), while in post monsoon/winter, it was due to burning of biomass and bursting of crackers in Diwali festival which increase fine-mode aerosol particles that show a positive correlation. Correlating the data between AOD and AE by Pearson correlation analysis revealed a significant positive correlation $(r=0.65, P<0.001)$. High AE value is observed in October to November because of stubble burning during the harvest season in Northern India. Also, bursting of crackers during the festival of Deepawali increases the finemode aerosol loading in the atmosphere.

\section{Health effects}

Air pollution now represents a considerable global pandemic and is one of the largest environmental health threats 

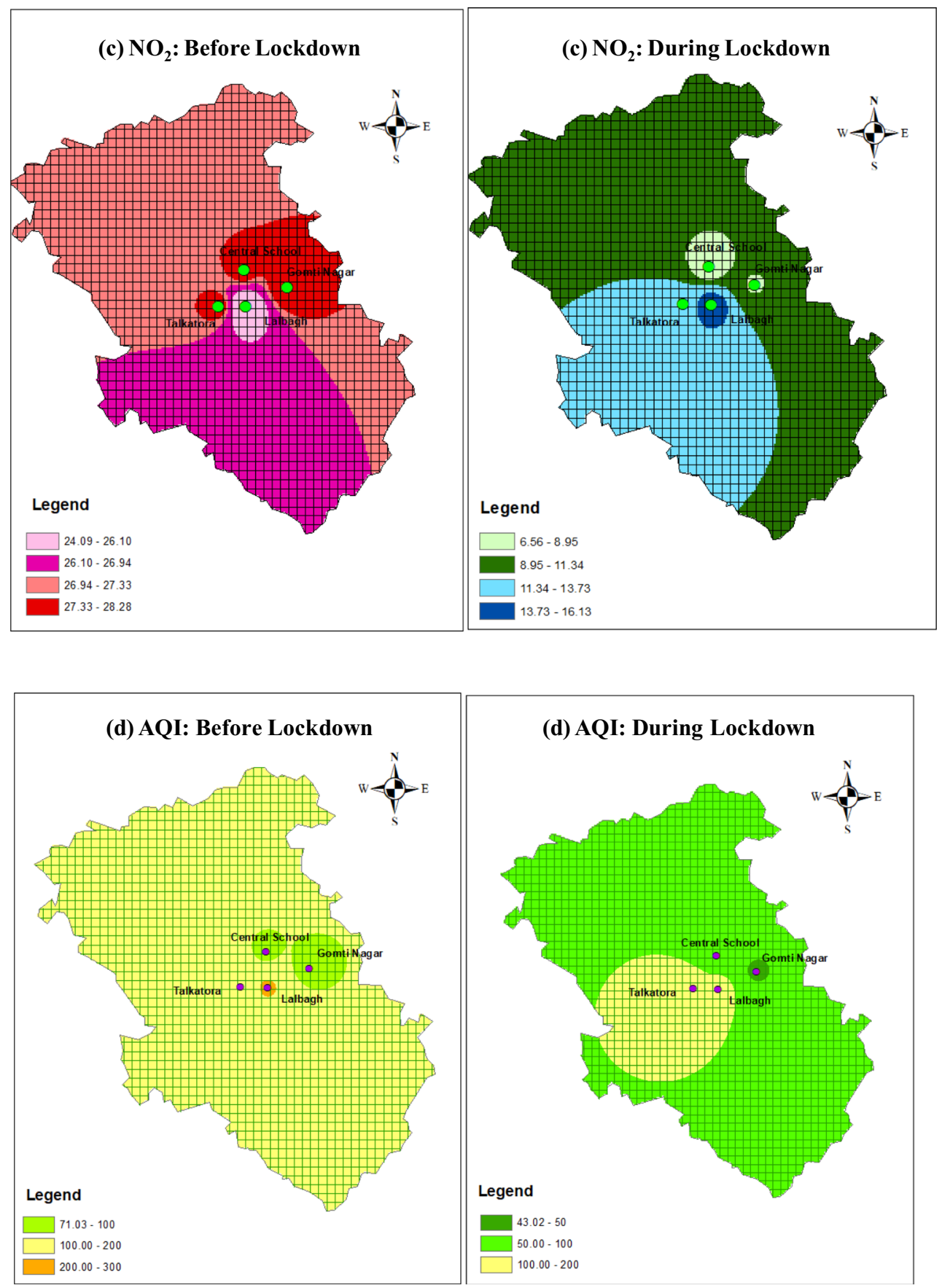

(d) AQI: During Lockdown

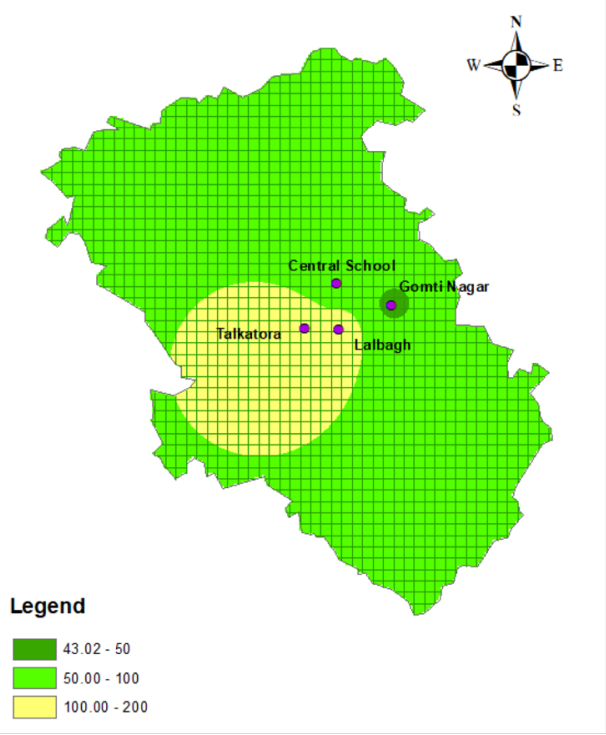

Fig. 3 (continued)

humanity faces. Though ambient air pollution affects developed and developing countries alike, low- and middle-income countries like India bear the maximum brunt. This silent killer is responsible for about 8 million premature deaths every year, mainly due to increasing incidents of cardiac arrests, compromised lung function, chronic obstructive pulmonary disease, asthma attacks and acute respiratory infections. The crux is that this devil called air pollution has created a total global panic and India as a developing country remains highly vulnerable.
PM is the most critical pollutant among all others from the health perspective. According to Global Burden of Disease Study 2015, exposure to fine particulate $\left(\mathrm{PM}_{2.5}\right)$ is the 5 th leading cause of death globally, causing 4.2 million deaths and 103.1 million disability-adjusted life-years in 2015 . Reinmuth-Selzle et al. (2017) also observed that PM was responsible for various types of allergies. Fourteen percent of all new cases of diabetes reported in 2016 were linked to air pollution, especially $\mathrm{PM}_{2.5}$, which enters the bloodstream through lungs and reduces insulin production and triggers 
Fig. 4 Annual variations of $\mathrm{AOD}_{550 \mathrm{~nm}}$ and $\mathrm{AE}_{412-470 \mathrm{~nm}}$ (annual mean AOD and AE are calculated by averaging all AOD and $\mathrm{AE}$ values for the same month during 2010 to 2019)

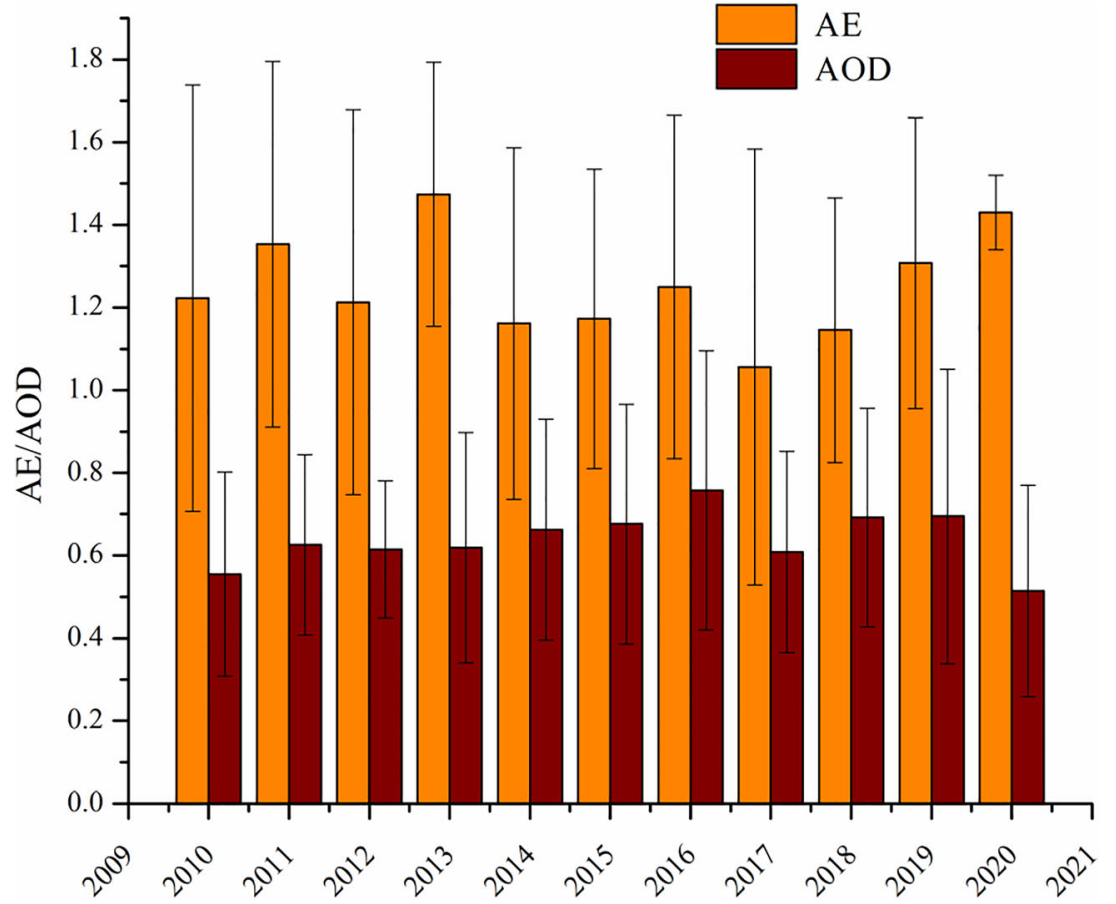

inflammation. Small-sized particles ranging from 0.001 to $0.1 \mu \mathrm{m}$ act as the carrier of pathogenic bacteria and viruses which may cause various types of lung infections including pneumonia. Moreover, these particles increase the rate of blood flow, damage the endothelial cell walls and may even cause cancer. They are also associated with elevated clotting activity, constriction of the airways and fever initiation. Ultrafine particles may cause imbalance between oxygen and carbon dioxide in the lungs. They also inhibit the function of alveolar ducts which basically assist the alveoli to collect the air that has been inhaled, and help in dispersing it to the alveolar sac.
It has been observed (Fig. 7) that the annual mean values of $\mathrm{PM}_{10}$ are more than three times the prescribed standard on $\mathrm{PM}_{10}$, i.e. $60 \mu \mathrm{g} / \mathrm{m}^{3}$ except 2019. Health impact of $\mathrm{PM}_{10}$ on post-neonatal mortality has been determined, and it has been observed that out of the total post-neonatal deaths, more than $1 / 4$ is due to exposure of $\mathrm{PM}_{10}$. This study also investigates the impact of $\mathrm{PM}_{2.5}$ which is more than twice of prescribed standards. It has been observed that the higher value of $\mathrm{PM}_{2.5}$ is responsible for $32 \%$ of deaths over the study period (2010 2019). On average, the attributable death rate per lakh population has been observed to be 202 which is much higher than
Fig. 5 Time series plot of $\mathrm{AOD}_{550 \mathrm{~nm}}$ and $\mathrm{AE}_{412-470 \mathrm{~nm}}$ with standard deviation over Lucknow for the period 2010 to 2019

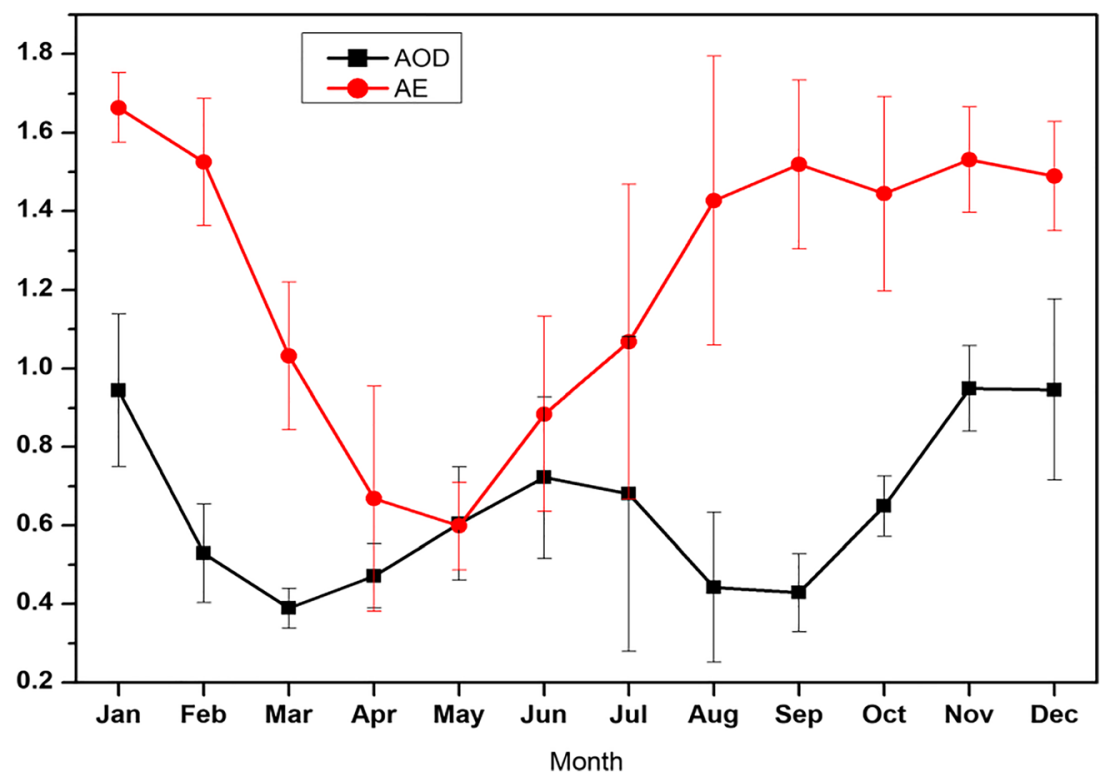



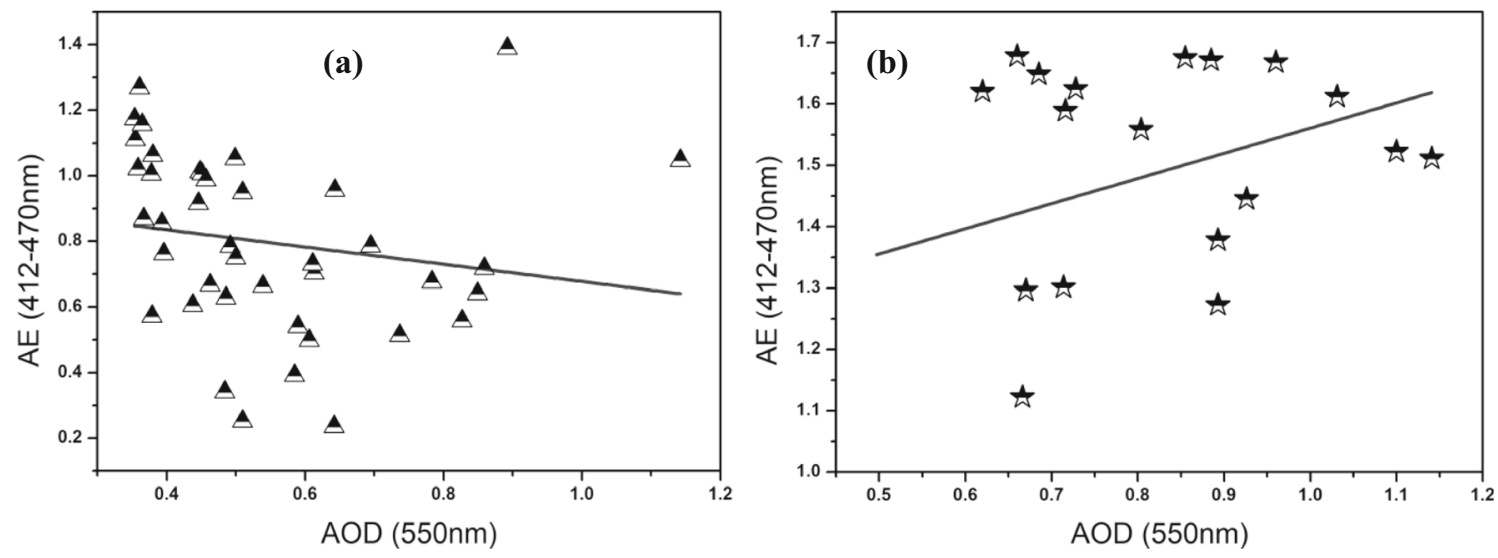

Fig. 6 Correlation between $\mathrm{AOD}_{550 \mathrm{~nm}}$ and $\mathrm{AE}_{412-470 \mathrm{~nm}}$ over Lucknow for the period 2010 to 2019

the nation's and state's attributable death rates, i.e. 89.9 and 111.1, respectively (Weiss et al. 2019).

$\mathrm{SO}_{2}$ is a highly reactive gas and is soluble in water so when inhaled via nose or mouth during breathing, it is mostly absorbed by mucosa and causes various types of allergies. It also causes coughing, wheezing, asthma and a tight feeling around the chest. Concentrations greater than $100 \mu \mathrm{g} / \mathrm{m}^{3}$ cause inflammation and irritation on the skin. Sometimes, the gas also reacts with other carcinogenic chemicals present in the atmosphere and changes into smaller-sized particles capable of penetrating deep into the lungs and inhibiting the process of gaseous exchange (Pool et al. 1988).

$\mathrm{NO}_{2}$ exposure may lead to increased asthma attacks and aggravated respiratory illnesses. Lesions in tissues connecting airways with the region of gaseous exchange may be formed with continuous exposure. There is inadequate evidence regarding $\mathrm{NO}_{2}$ as a potential carcinogen. However, it is considered that $\mathrm{NO}_{2}$ could produce nitrates and nitrites by reacting with amines forming nitrosamines which are carcinogenic agents (Song et al. 2015).

$\mathrm{Pb}$ poisoning is called as plumbism, colica pictorial or painter's colic. It is one such pollutant which, when enters the human body, is hard to flush out. $\mathrm{Pb}$ interferes with many body processes and affects almost all organ systems. It damages the central nervous system and is therefore particularly toxic to children who absorb the pollutant at a faster rate than adults. It binds with the sulphydryl group present on many enzymes and mimics other metals which act as cofactors in enzymatic reactions. It also interferes in heme synthesis leading to anaemia. In the brain, it is able to pass the blood-brain barrier by substituting the calcium ions causing a neuromuscular disease called as $\mathrm{Pb}$ palsy. $\mathrm{Pb}$ tends to accumulate in the environment and enters the food chain.

$\mathrm{Ni}$ is particularly toxic to human beings and is a known carcinogen. Incidences of lung, kidney and prostate cancers have been reported in workers exposed to high concentrations of $\mathrm{Ni}$. Ni in combination with carbon group forms a highly poisonous gas $\left(\mathrm{Ni}(\mathrm{CO})_{4}\right)$. Sensitive people may develop allergy to nickel which affects their skin (US EPA 1999). This condition is known as contact dermatitis. Ni may also impair the development of embryo, leading to congenital defects.

Aerosols have an enormous effect on the Earth's climate system and air quality, which significantly affects human health. Various epidemiological studies associate aerosols with dire health effects like increased mortality, respiratory illness and cardiovascular diseases. Ultrafine particle $(\mathrm{dp}<$ $100 \mathrm{~nm}$ ) are particularly hazardous to humans as these are small enough to pass through the membranes of the respiratory tract and enter the bloodstream. They can also be transported along olfactory nerves into the brain. Bio-
Fig. 7 Health impacts attributable to long-term exposure to $\mathrm{PM}_{10}$ (post-neonatal infant mortality) and $\mathrm{PM}_{2.5}$ (mortality from all causes). The confidence intervals (lower and upper) for the number of excess cases are indicated using bars

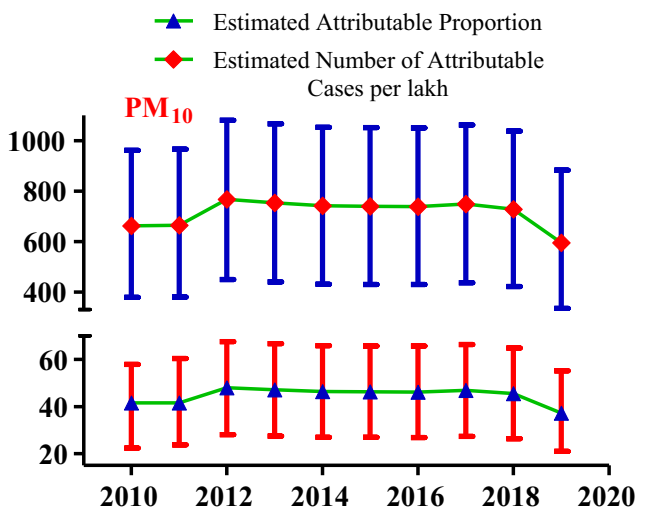


aerosols are segment of atmospheric particulate matter that are released from terrestrial and marine ecosystems into the atmospheres. These include a wide variety of living and dead components like bacteria, viruses, fungi, dispersal units like pollen grains and fungal spores and also cellular material from animals and plants. Fröhlich-Nowoisky et al. (2016) also suggested that aerosols work as a carrier of various living and dead components. There is still a dearth of evidence to establish a clear correlation between the physical and chemical properties of ultrafine and large aerosols that actually have adverse health effects on human beings. Bio-aerosols may be allergenic and infectious to living organisms, which influence human health and agriculture on regional and global levels (Reinmuth-Selzle et al. 2017). The health effect of aerosols can be broadly classified into two categories, namely short-term and acute effects like asthmatic attacks and bronchitis and long-term chronic effects like infectious diseases, respiratory allergies and cancer.

\section{Conclusions}

The present research concluded that the level of atmospheric particulate matter in all considered locations remained much above the standard prescribed limits, all throughout the stated period. The maximum average concentration of $\mathrm{PM}_{10}$ and $\mathrm{PM}_{2.5}$ were 226.55 and $115.0 \mu \mathrm{g} / \mathrm{m}^{3}, 270.75$ and $111.55 \mu \mathrm{g} /$ $\mathrm{m}^{3}$ and 225.60 and $124.95 \mu \mathrm{g} / \mathrm{m}^{3}$ for residential, commercial and industrial areas, respectively. Charbagh and Chowk had the highest particulate pollution possibly due to excessive vehicular movement, increased construction activities, open garbage burning, commercial and industrial activities, etc. Saving $\mathrm{SO}_{2}$, the observed values of all the other pollutants were higher than the NAAQS standards and this is what has fast transformed the city into an air pollution epicenter, grappling with diseases like ischaemic heart disease, stroke, lung cancer, COPD and acute respiratory infections. On an average, the attributable death rate per lakh population has been observed as 202 in the case of $\mathrm{PM}_{2.5}$ for all causes and 714 in the case of $\mathrm{PM}_{10}$ for post-neonatal death which is much higher than the nation's and state's attributable death rates. Amid the consequences of the coronavirus lockdown, the ambient air quality of the city improved considerably, bringing the AQI score into the safe and healthy category. The maximum impact was seen in the PM values of the areas in which high PM levels were reported earlier, historically. Since this is a temporary relief, the need of the hour is to implement long-term measures like strengthening the public transport system, discouraging the use of private vehicles by imposing healthy congestion charges, checking dieselization, offering scrappage schemes for most polluting vehicles, providing for compulsory tarpaulin or protective canvas around construction sites and blanket ban on burning of waste to keep the health hazards at bay.
Acknowledgements The first author is highly grateful to the Director, CSIR-IITR, Lucknow, for providing the necessary facilities for this research. Furthermore, we would like to thankfully acknowledge the MODIS Terra and Aqua part of NASA team for providing the satellite data on online visualization and analysis infrastructure (Giovanni).

Authors' contributions The main investigator was Markandeya, who designed the manuscript. The technical drafting of the manuscript was done by NKS, while VM and PKV helped in the writing and data collection, respectively. Moreover, SPS and DM were advisors of the present research. All the authors have read and approved the manuscript.

Data availability The datasets used and/or analyzed during the current study are available from the corresponding author on reasonable request.

\section{Compliance with ethical standards}

Competing interests The authors declare that they have no competing interests.

Ethical approval and consent to participate Not applicable

Consent for publication Not applicable

\section{References}

Air Quality Index by Central Pollution Control Board (2020) http://www. cpcb.gov.in/CAAQM/frmCurrentDataNew.aspx?StationName= Ihbas \&StateId $=6 \&$ CityId $=85$ Accessed 25-5 April-May 2020

Assessment of ambient air quality of Lucknow City (2010-2019) CSIR Indian Institute of Toxicology Research (CSIR-IITR), Lucknow. http://iitrindia.org/En/environmental_status_reports.aspx. Accessed 25-5 April-May 2020

Atkinson RW, Butland BK, Anderson HR, Maynard RL (2018) Longterm concentrations of nitrogen dioxide and mortality: a metaanalysis of cohort studies. Epidemiology 29(4):460-472. https:// doi.org/10.1097/EDE.0000000000000847

Barman SC, Singh R, Negi MPS, Bhargava SK (2008) Ambient air quality of Lucknow City (India) during use of fireworks on Diwali festival. Environ Monit Assess 137:495-504. https://doi.org/10.1007/ s10661-007-9784-1

Beig G, Chate DM, Ghude SD, Mahajan AS, Srinivas R, Ali K, Sahu SK, Parkhi N, Surendran D, Trimbake HR (2013) Quantifying the effect of air quality control measures during the 2010 Commonwealth Games at Delhi, India. Atmos Environ 80:455-463. https://doi. org/10.1016/j.atmosenv.2013.08.012

Central Pollution Control Board (CPCB) annual report, 2006-2007. http://164.100.107.13/upload/AnnualReports/AnnualReport_34 Annual-Report-06-07.pdf

Das SK, Jayaraman A (2011) Role of black carbon in aerosol properties and radiative forcing over Western India during premonsoon period. Atmos Res 102(3):320-334

Das S, Dey S, Dash SK, Giuliani G, Solmon F (2015) Dust aerosol feedback on the Indian summer monsoon: sensitivity to absorption property. J Geophys Res-Atmos 120(18):9642-9652

Fröhlich-Nowoisky J, Christopher JK, Weber B, Huffman JA, Pöhlker C, Andreae MO, Lang-Yona N, Burrows SM, Gunthe SS, Elbert W, Su H, Hoor P, Thines E, Hoffmann T, Després VR, Pöschl U (2016) Bioaerosols in the earth system: climate, health, and ecosystem interactions. Atmos Res 182:346-376. https://doi.org/10.1016/j. atmosres.2016.07.018 
Ghorani-Azam A, Riahi-Zanjani B, Balali-Mood M (2016) Effects of air pollution on human health and practical measures for prevention in Iran. J Res Med Sci 21:-65. https://doi.org/10.4103/1735-1995. 189646

Ghosh R, Chakraborty A, Nanjundiah RS (2018) Relative role of premonsoon conditions and intra-seasonal oscillations in determining early-vs-late Indian monsoon intensity in a GCM. Theor Appl Climatol 131:319-333. https://doi.org/10.1007/s00704-016-1970-z

Gupta P, Khan MN, da Silva A, Patadia F (2013) MODIS aerosol optical depth observations over urban areas in Pakistan: quantity and quality of the data for air quality monitoring. Atmos Pollut Res 4:43-52

Gurjar BR, Ravindra K, Nagpure AS (2016) Air pollution trends over Indian megacities and their local-to-global implications. Atmos Environ 142:475-449. https://doi.org/10.1016/j.atmosenv.2016.06. 030

Hai DN, Tung LV, Van DK, Binh TT, Phuong HL, Trung ND, Son ND, Giang HT, Hung NM, Khue PM (2018) Lead environmental pollution and childhood lead poisoning at Ban Thi Commune, Bac Kan Province, Vietnam. Biomed Res Int:5156812. https://doi.org/10. $1155 / 2018 / 5156812$

Havens D, Pham MH, Karr CJ, Daniell WE (2018) Blood lead levels and risk factors for lead exposure in a pediatric population in Ho Chi Minh City, Vietnam. Int J Environ Res Public Health 15(1). https:// doi.org/10.3390/ijerph15010093

Kumar M, Parmar KS, Kumar DB, Mhawish A, Broday DM, Mall RK, Banerjee T (2018) Long-term aerosol climatology over IndoGangetic Plain: trend, prediction and potential source fields. Atmos Environ 180:37-50. https://doi.org/10.1016/j.atmosenv. 2018.02.027

Kumar S, Srivastava AK, Pathak V, Bisht DS, Tiwari S (2019) Surface solar radiation and its association with aerosol characteristics at an urban station in the Indo-Gangetic Basin: implication to radiative effect. J Atmos Sol Terr Phys 193:105061. https://doi.org/10.1016/j. jastp.2019.105061

Markandeya, Shukla SP, Kisku GC (2015) Linear and non-linear kinetic modeling for the adsorption of disperse dye in a batch process. Res $\mathrm{J}$ Environ Toxicol 9(6):320-331

Markandeya, Pratap D, Kumar V, Shukla NK (2016a) Seasonal variation of ozone in industrial area of Singrauli, India. Middle-East J Sci Res 24(1):11-14. https://doi.org/10.5829/idosi.mejsr.2016.24.01.22566

Markandeya, Shukla SP, Kisku GC (2016b) A clean technology for future prospective: emission modeling of gas based power plant. Open J Air Pollut 5:144-159. https://doi.org/10.4236/ojap.2016.54011

Markandeya, Kisku GC, Shukla SP (2017) Role of aerosols in climate change and cloud formation emission released from coal based power plant. SF J Glob Warm 1(1):1-7

National ambient air quality standards by Central Pollution Control Board. Notification New Delhi. 2009. https://scclmines.com/env/ DOCS/NAAQS-2009.pdf.\&nbsp;Accessed 25-5 April-May 2020

Pandey P, Khan AH, Verma AK, Singh KA, Mathur N, Kisku GC, Barman SC (2011) Seasonal trends of $\mathrm{PM}_{2.5}$ and $\mathrm{PM}_{10}$ in ambient air and their correlation in ambient air of Lucknow City, India. B Environ Contam Tox 88(2):265-270. https://doi.org/10.1007/ s00128-011-0466-x

Pandey P, Patel DK, Khan AH, Barman SC, Murthy RC, Kisku GC (2013) Temporal distribution of fine particulates $\left(\mathrm{PM}_{2.5}, \mathrm{PM}_{10}\right)$, potentially toxic metals, PAHs and metal-bound carcinogenic risk in the population of Lucknow City, India. Journal of Environmental Science and Health, Part A: Toxic/Hazardous Substances and Environmental Engineering 48(7):730-745

Pathak H, Bhatia A (2018) Reactive nitrogen and its impacts on climate change: an Indian synthesis. The Indian Nitrogen Assessment Elsevier 383-401. https://doi.org/10.1016/B978-0-12-811836-8. 00024-0

Pool BL, Janowsky I, Klein P, Klein RG, Schmezer P, Vogt-Leucht G, Zeller WJ (1988) Effects of $\mathrm{SO}_{2}$ or NOx on toxic and genotoxic properties of chemical carcinogens. I. In vitro studies. Carcinogenesis 9(7):1237-1245

Reinmuth-Selzle K, Kampf CJ, Lucas K, Lang-Yona N, FröhlichNowoisky J, Shiraiwa M, Lakey PSJ, Lai S, Liu F, Kunert AT, Ziegler K, Shen F, Sgarbanti R, Weber B, Bellinghausen I, Saloga J, Weller MG, Duschl A, Schuppan D, Pöschl U (2017) Air pollution and climate change effects on allergies in the anthropocene: abundance, interaction, and modification of allergens and adjuvants. Environ Sci Technol 51(8):4119-4141. https://doi.org/10.1021/acs. est.6b04908

Satterthwaite D, McGranahan G, Tacoli C (2010) Urbanization and its implications for food and farming. Philos Trans R Soc Lond Ser B Biol Sci 365(1554):2809-2820. https://doi.org/10.1098/rstb.2010. 0136

Seinfeld JH, Pandis SN (1998) From air pollution to climate change. Atmospheric chemistry and physics, 3rd edn, p 1152 ISBN: 978 1-118-94740-1

Shen X, Bilal M, Qiu Z, Sun D, Wang S, Zhu W (2019) Long-term spatiotemporal variations of aerosol optical depth over Yellow and Bohai Sea. Environ Sci Pollut Res 26:7969-7979

Shukla JB, Misra AK, Sundar S, Naresh R (2008) Effect of rain on removal of a gaseous pollutant and two different particulate matters from the atmosphere of a city. Math Comput Model 48(5-6):832844. https://doi.org/10.1016/j.mcm.2007.10.016

Song P, Wu L, Guan W (2015) Dietary nitrates, nitrites, and nitrosamines intake and the risk of gastric cancer: a meta-analysis. Nutrients. 7(12):9872-9895. https://doi.org/10.3390/nu7125505

Srivastava AK, Singh S, Tiwari S, Bisht DS (2012) Contribution of anthropogenic aerosols in direct radiative forcing and atmospheric heating rate over Delhi in the Indo-Gangatic Basin. Environ Sci Pollut Res 19:1144-1158

Tiwari M, Shukla SP, Shukla NK, Singh RB, Mumtaz N, Gupta VK, Singh V (2014) Emission profile of pollutants due to traffic in Lucknow City, India. Int Res J Public Environ Health 1(7):150 157. https://doi.org/10.15739/irjpeh.001

Tiwari S, Srivastava AK, Singh AK, Singh S (2015) Identification of aerosol types over Indo-Gangetic Basin: implications to optical properties and associated radiative forcing. Environ Sci Pollut Res 22:12246-12260

Tiwari S, Singh RK, Srivastava AK, Soni VK, Tiwari S, Singh RS, Srivastava MK, Singh AK (2018) Identification of aerosol sources and its characterization at Varanasi: an air mass based study. Int J Earth Atmos Sci 5(1):19-35

U.S. Environmental Protection Agency (1999) Integrated Risk Information System (IRIS) on nickel carbonyl. National Center for Environmental Assessment. Office of Research and Development, Washington, DC

Weiss DJ, Lucas TCD, Nguyen M, Nandi AK, Bisanzio D, Battle KE, Cameron E, Twohig KA, Pfeffer DA, Rozier JA, Gibson HS, Rao PC, Casey D, Bertozzi-Villa Amelia, Collins EL, Dalrymple U, Gray N, Harris JR, Howes RE, Kang SY, Keddie SH, May D, Rumisha S, Thorn MP, Barber R, Fullman N, Huynh CK, Kulikoff X, Kutz, MJ, Lopez AD, Mokdad AH, Naghavi M, Nguyen G, Shackelford K, Vos AT, Wang H, Smith DL, Lim SS, Murray CJL, Bhatt S, Hay SI, Gething PW (2019) Mapping the global prevalence, incidence, and mortality of Plasmodium falciparum, 2000-17: a spatial and temporal modelling study, The Lancet 394(10195):322-331. https://doi.org/10.1016/S01406736(19)31097-9

WHO (2006) Use of air quality guidelines in protecting public health: global update. Available at http://www.who.int/mediacentre/ factsheets/fs313/enS. Accessed 25-5 April-May 2020

WHO, Global Urban Ambient Air Pollution Database (2016) Ambient air pollution: a global assessment of exposure and burden of disease. In: World Health Organization https://www.who.int/phe/publications/ air-pollution-global-assessment/en/. Accessed 25-5 April-May 2020 
Winkler SL, Anderson JE, Garza L, Ruona WC, Vogt R, Wallington TJ (2018) Vehicle criteria pollutant (PM, NOx, CO, HCs) emissions: how low should we go? NPJ Clim Atmos Sci\&nbsp;1:26. https:// doi.org/10.1038/s41612-018-0037-5

World air quality report-IQAir (2019) https://www.iqair.com/worldmost-polluted-cities/world-air-quality-report-2019-en.pdf. Accessed 25-5 April-May 2020

Wu SP, Cai MJ, Xu C, Zhang N, Zhou JB, Yan JP, Schwab JJ, Yuan CS (2020) Chemical nature of $\mathrm{PM}_{2.5}$ and $\mathrm{PM}_{10}$ in the coastal urban Xiamen, China: insights into the impacts of shipping emissions and health risk. Atmos Environ 227:117383. https://doi.org/10. 1016/j.atmosenv.2020.117383
You Y, Zhao T, Xie Y, Zheng Y, Zhu J, Xia J, Cao L, Wang C, Che H, Liao Y, Duan J, Zhou J, Zhou X (2020) Variation of the aerosol optical properties and validation of MODIS AOD products over the eastern edge of the Tibetan Plateau based on ground-based remote sensing in 2017. Atmos Environ. https://doi.org/10.1016/j. atmosenv.2019.117257

Zhang K, Batterman S (2013) Air pollution and health risks due to vehicle traffic. Sci Total Environ 450-451:307-316. https://doi.org/10. 1016/j.scitotenv.2013.01.074

Publisher's note Springer Nature remains neutral with regard to jurisdictional claims in published maps and institutional affiliations. 